\title{
Two Asian Films
}

\author{
By Toh, Hai Leong \\ Spring 1998 Issue of KINEMA
}

\begin{abstract}
DESTINATION: $9^{\text {th }}$ HEAVEN (Hong Kong-China, 1997). Dir: Wong Chun Man. Cast: Tony Leung Kar-fai, Pan Hong, Gigi Lai, Christine Ng, Sunny Chan, Lau Ying Hung. IRON SISTER (Taiwan-China, 1997). Dir: Yeh Hung-wai. Cast: Shu Qi.
\end{abstract}

Destination: $9^{\text {th }}$ Heaven stars Tony Leung Kar-fai ( The Lover), Winston Chao (Eat Drink Man Woman) together with the Mainland Chinese veteran actress Pan Hong. Produced by the shrewd veteran actor-producer Raymond Wong, the film is a tale of love and business rivalry set in Hongkong and Tianjin (Tientsin).

Iron Sister is adroitly directed by one of Taiwan's foremost New Wave filmmakers, Yeh Hung-wai who gained international prominence with a made in China film Five Girls And A Rope two years back. His latest work features the promising Taiwanese star Shu Qi (last seen in Derek Yee's satire Viva Erotica) who plays a tenacious huntress called Iron Sister Suen.

The settings of both films present an interesting contrast: $9^{\text {th }}$ Heaven is set in the highly competitive urban jungle in which business protagonists and rocket physicists play out their game of intrigue and survival. On the other hand, Iron Sister takes place in the harsh rural landscape of northern China during the 1940s Japanese occupation.

In $9^{\text {th }}$ Heaven Winston Chao, usually typecast as an unhappily married businessman, plays a scrupulously patriotic Chin Ching who has his mind fixed on launching into orbit the Hong Kong Star Satellite. Seven years ago, Chin had a failed love affair with a younger businesswoman, Joey (Christine Ng); she is now back in his life but is wooed by Chan Hing (Sunny Chan), the business partner of her unscrupulous brother Jovan. In order to get her money for their shady business deals,..Jovan hatches a scheme for Chan to seduce and marry his "spinster" sister to realise their ambition. A subplot involves Chin's daughter, Mona (Gigi Lai) who falls for a rocket researcher Chiang San (Tony Leung) whom she had earlier rebuffed., despite knowing that he is dedicated to his wife Hai Yen (Pan Hong, one of China's top actresses).

This dual ménage à trois is a little too much to handle and in shifting between the two love triangles (with the obvious bow to China's progress in rocket technology), the film wavers. Fortunately, with Tony Leung's pared-down acting and Pan Hong's dignified portrayal of the tolerant and understanding wife, the film maintains some measure of quality.

Yeh's Iron Sister is a probing work about ingratitude, betrayal and unrequited love. Through facial gestures, the well-composed music and the actors' understatement, the audience feels the indecisiveness of the villainous Tung Fei motivated by greed as much as his desire for his mistress. And yet he denies himself his conjugal rights by not forcing himself on his wife, Iron Sister, who marries him for money. For a TaiwaneseMainland Chinese film, the treatment of sexuality is a breakthrough of sorts. Although there is an element of exploitation, it is placed in the context of a credible story. Thus, even Shu Qi's nude scene (this broke the artist's earlier promise not to disrobe), ceased to be a bone of contention for the film's critics. Despite its low-key publicity, Iron Sister will surely be welcomed at many international film festivals.

\section{Author Information}

TOH Hai Leong is a Singapore-based freelance film critic and filmmaker (Zombie Dogs, 2005) who writes for independent film publications such as Screen International and World Paper. He has covered the Hong Kong International Film Festival since 1985 and specializes in the cinemas of Hong Kong, Taiwan, China, Korea and Japan. 


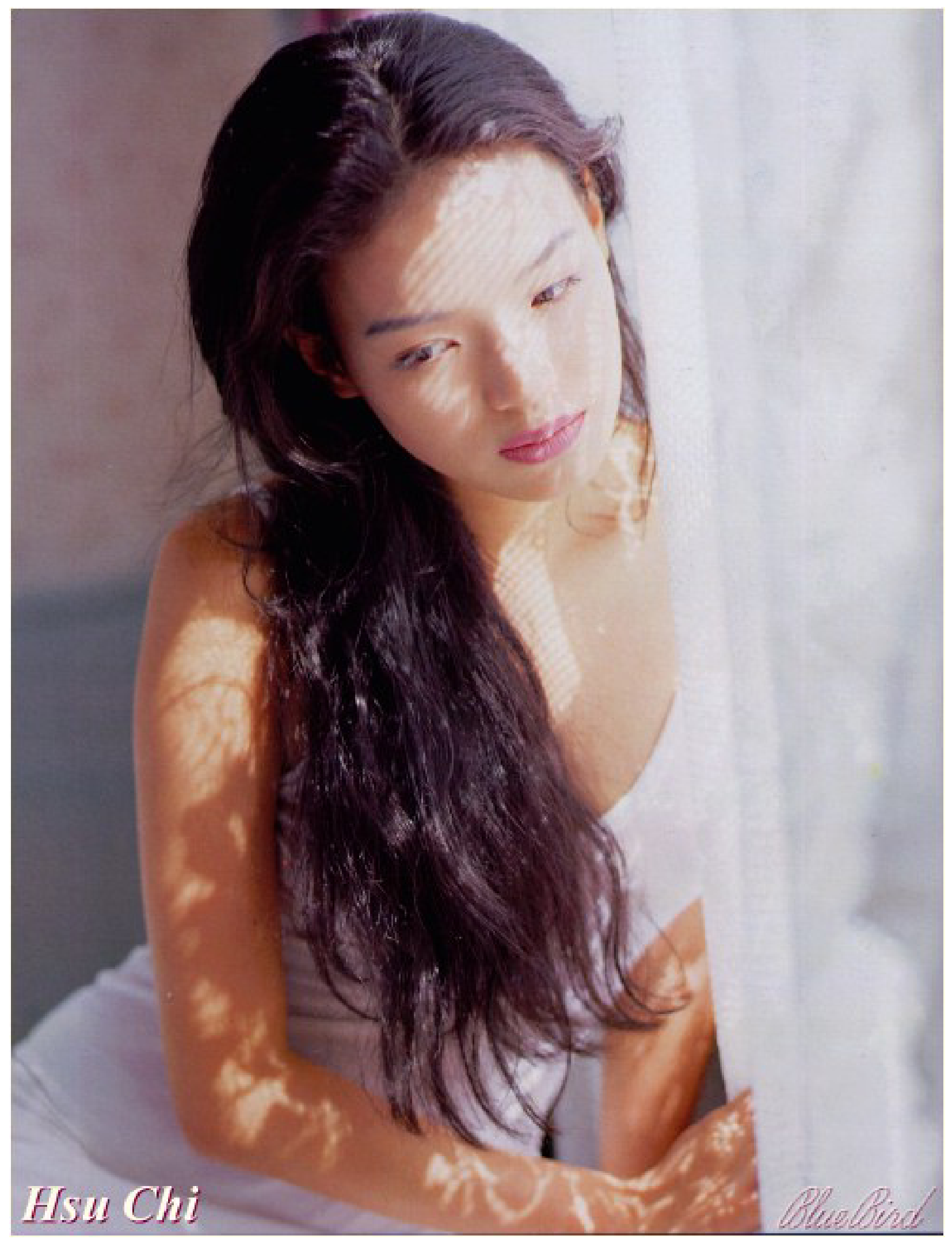

Figure 1: Actress Shu Qi (Hsu Chi) 